\title{
Correlation between muscular edema on magnetic resonance imaging versus major histocompatibility complex type II overexpression on muscle biopsy at diagnosis on juvenile dermatomyositis patients
}

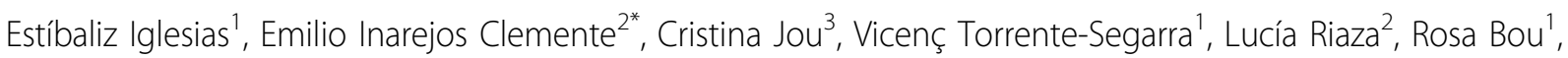 \\ Teresa Ribalta ${ }^{3}$, Jordi Antón ${ }^{1}$
}

From 21st European Pediatric Rheumatology (PReS) Congress

Belgrade, Serbia. 17-21 September 2014

\section{Introduction}

Juvenile Dermatomyositis (JDM) is the most common idiopathic inflammatory myopathy in childhood. Magnetic resonance imaging (MRI) is a non invasive tool to assess muscular edema. Its ability to distinguish between active JDM patients and inactive and healthy children is well described in the literature. However muscle biopsy still remains the gold standard in JDM diagnosis. Major Histocompatibility Complex (MHC) type I is overexpressed on sarcolemma of inflammatory myopathies and it could be detectable before inflammatory infiltrate appears on conventional tecniques and remains there in spite of treatment.

\section{Objectives}

To assess clinical characteristics, muscular MRI pattern and MHC type I overexpression on sarcolemma and sarcoplasma on muscle biopsy at diagnosis of our JDM patients among 2000 and 2013.

\section{Methods}

We made a retrospective chart, including MRI and muscle biopsies. Muscular edema, fascia involvement and soft tissue edema were assessed by a Pediatric Radiologist on paravertebral and scapular and pelvic girdle muscles and scored as present or not and defined as patchy or diffuse.

2Diagnostic Imaging, Hospital Sant Joan De Déu, Esplugues De Llobregat, Barcelona, Spain

Full list of author information is available at the end of the article
Muscle biopsies were evaluated with conventional tecniques (hematoxiline-eosine and tricromique) and MHC type I inmunohistochemical study. We evaluated perifascicular atrophy, regenerated and necrotic fibers and inflamatory infiltrated, being pathological the presence of one of the aforementioned. We study the MHC type I overexpression on sarcolemma and sarcoplasma scored as mild $=1$, moderate $=2$ and severe $=3$, describing as well the percentage of affected muscle fibers. The results were assessed by a neuropathologist.

\section{Results}

23 patients were included. Demographic and clinical characteristics are summarized on table 1. MRI: 16 patients had MRI at diagnosis being pathological in 15 . Thigh muscles were the most frequently affected (93\% vs $86 \%$ and $79 \%$ of arm and paravertebral muscles respectively) and diffuse pattern more common than patchy one. 5 patients had soft tissue edema, 4 of these with fascia edema too. Muscle biopsy: 18 patients had muscle biopsy at diagnosis. All biopsied muscles except one were pathological on simultaneously MRI. Histological study show muscle affectation in 14 out of 18 patients but all patients overexpressed MHC type I on sarcolemma and sarcoplasma with $100 \%$ of fibers affected and a range of $50-100 \%$ and $15-100 \%$ on sarcolemma and sarcoplasma respectively. Median intensity scored on sarcolemma and sarcoplasma was $3[1-3]$ and 1,5 [1-2]. 


\section{Conclusion}

MRI is an important non invasive tool to evaluate muscular edema in JDM patients but MHC type I overexpression on muscle biopsy seems to be the most sensitive technique for diagnosis at this moment. All our patients overexpressed MHC type I on sarcolemma and sarcoplasma, despite some of them had normal histology.

\section{Disclosure of interest}

None declared.

\section{Authors' details}

'Pediatric Rheumatology, Hospital Sant Joan De Déu, Esplugues De Llobregat, Barcelona, Spain. ${ }^{2}$ Diagnostic Imaging, Hospital Sant Joan De Déu, Esplugues De Llobregat, Barcelona, Spain. ${ }^{3}$ Pathology, Hospital Sant Joan De Déu, Esplugues De Llobregat, Barcelona, Spain.

Published: 17 September 2014

doi:10.1186/1546-0096-12-S1-P90

Cite this article as: Iglesias et al: Correlation between muscular edema on magnetic resonance imaging versus major histocompatibility complex type II overexpression on muscle biopsy at diagnosis on juvenile dermatomyositis patients. Pediatric Rheumatology 201412 (Suppl 1):P90

Submit your next manuscript to BioMed Central and take full advantage of:

- Convenient online submission

- Thorough peer review

- No space constraints or color figure charges

- Immediate publication on acceptance

- Inclusion in PubMed, CAS, Scopus and Google Scholar

- Research which is freely available for redistribution

Submit your manuscript at www.biomedcentral.com/submit 